\title{
Variations of zooplankton metabolism and feeding in the frontal area of the Alboran Sea (western Mediterranean) in winter
}

\section{Variations du métabolisme et de la nutrition du zooplancton dans la région frontale de la mer d'Alboran (Méditerranée occidentale) en hiver}

\author{
Raymond Gaudy *, Faiçal Youssara \\ Centre d'Océanologie de Marseille, LOB (URA CNRS 6535), Station marine d'Endoume, rue de la Batterie des lions, 13007 Marseille, France
}

Received 1 June 2002; received in revised form 11 October 2002; accepted 13 October 2002

\begin{abstract}
Respiration, excretion $\left(\mathrm{NH}_{4}\right.$ and $\left.\mathrm{PO}_{4}\right)$ and feeding of zooplankton from the upper $200 \mathrm{~m}$ of the Almeria-Oran frontal region (western Mediterranean), were studied during winter 1997. Eight sites belonging to the three main hydrodynamic structures of the area (Mediterranean water, geostrophic Atlantic jet and associated anticyclonic gyre) were considered. Lowest values of respiration, $\mathrm{PO}_{4}$ excretion, $\mathrm{O} / \mathrm{P}$ atomic ratio and particle ingestion were found in Mediterranean waters. At the frontal limit, respiration and ammonium excretion were enhanced compared to the adjacent structures (Mediterranean water and Atlantic jet). In the gyre water, lowest $\mathrm{O} / \mathrm{N}$ and highest N/P values were observed and maximum faecal pellet production and reproduction activity (inferred from the proportion of nauplii in plankton) were recorded. Selectivity was observed for feeding with respect to particular spectra. At the front and in the jet, large particles $(>20 \mu \mathrm{m})$, were preferred, while medium- and small-sized particles were mainly used for food at the gyre and in Mediterranean water. As the bulk of zooplankton components was the same at all the stations, physiological variations were interpreted as adaptive processes to qualitative and quantitative changes in the food resource, i.e. Mediterranean scarcity and Atlantic water richness, "new production" of diatoms at the front limit, enhancement of the microbial food chain at the gyre and in Mediterranean waters. The maximum proportion of copepod nauplii observed at the gyre could result, either from an isopycnal transport from the front, of larvae issued from eggs produced at the frontal limit, or from a local enhancement of copepod reproductive activity induced by the favourable food conditions prevailing at the gyre, as suggested by the increase of faecal production.
\end{abstract}

(c) 2003 Éditions scientifiques et médicales Elsevier SAS. All rights reserved.

\section{Résumé}

La respiration, l'excrétion $\left(\mathrm{NH}_{4}\right.$ et $\left.\mathrm{PO}_{4}\right)$ et la nutrition du zooplancton des deux cents premiers mètres de la région du front Alméria-Oran (Méditerranée occidentale) ont été étudiées pendant l'hiver 1997. Huit sites appartenant aux trois principales structures hydrodynamiques de la région (eau méditerranéenne, jet géostrophique atlantique et tourbillon anticyclonique associé) ont été considérés. Les plus basses valeurs de respiration, d'excrétion de $\mathrm{PO}_{4}$, du rapport atomique $\mathrm{O} / \mathrm{N}$ et d'ingestion de particules ont été trouvées dans les eaux méditerranéennes. À la limite frontale, les taux de respiration et d'excrétion d'ammonium sont plus élevés que dans les structures adjacentes (eau méditerranéenne et jet atlantique). Dans le tourbillon, les valeurs les plus faibles de $\mathrm{O} / \mathrm{N}$ et les plus élevées de N/P ont été observées et les taux maximum de production fécale et d'activité de reproduction (estimée d'après la proportion de nauplii dans le plancton) ont été enregistrés. Une sélectivité a été observée pour le choix de la nourriture en fonction du spectre particulaire. Au front et dans le jet, les grandes particules (> $20 \mu \mathrm{m})$, relativement abondantes, sont préférées alors que dans le tourbillon et dans l'eau méditerranéenne, ce sont les particules de moyenne et de petite taille qui ont surtout été utilisées comme nourriture. L'essentiel de la composition spécifique du zooplancton étant la même à toutes les stations, les variations physiologiques sont interprétées comme des processus adaptatifs vis-à-vis des changements qualitatifs et quantitatifs de la ressource nutritive (pauvreté méditerranéenne et richesse atlantique, «production nouvelle » de diatomées à la limite frontale, accroissement d'activité de la chaîne microbienne dans le tourbillon et dans l'eau méditerranéenne). La plus grande proportion de nauplii de copépodes observée dans le tourbillon pourrait résulter soit d'un transport isopycnal à partir du front, de larves issues des œufs produits à sa limite, soit

* Corresponding author.

E-mail address: gaudy@ com.univ-mrs.fr (R. Gaudy). 
d'un accroissement local de l'activité de reproduction induit par les conditions nutritionnelles favorables de l'eau du tourbillon comme le suggère l'accroissement de la production de fèces.

(C) 2003 Éditions scientifiques et médicales Elsevier SAS. Tous droits réservés.

Keywords: Alboran sea; Front; Zooplankton; Metabolism; Feeding

Mots clés : Mer d'Alboran ; Front ; Zooplancton ; Métabolisme ; Nutrition

\section{Introduction}

Frontal regions often harbour higher phytoplankton biomass than adjacent areas (Le Fèvre, 1986). Geostrophic fronts exhibit complex structures where the primary current circulation (related to the geostrophic situation) is accompanied by a cross frontal secondary circulation associated with divergence and convergence areas, which usually promote primary production in the surface water. Inflow of Atlantic water in the western basin of the Mediterranean sea through the Gibraltar strait induces such a frontal structure. It is characterised by its large extent (length $200 \mathrm{~km}$ ) and the existence of a strong horizontal gradient of density (> $0.4 \mathrm{~kg} \mathrm{~m}^{-3}$ for $10 \mathrm{~km}$ (Prieur and Sournia, 1994)). The inflow of Atlantic water forms two anticyclonic gyres (a western and an eastern one), occupying all the Alboran sea. The eastern structure generally starts near the Cape Tres forcas, in Algeria, proceeds to the Spanish coasts, near Almeria, then constitutes a well-defined jet flowing in the SE direction towards Cape Gata and Oran (Algeria), associated in its southern part with an anticyclonic gyre of Atlantic water (Tintore et al., 1988). The left side of the jet forms a well-marked density gradient, clearly visible on the satellite images (Arnone et al., 1990; Folkard et al., 1994). This permanent structure (Almeria-Oran front) was presumed to play a significant role in the biological productivity at the regional scale (Prieur et al., 1993).

This was demonstrated by the data obtained during the "Almofront 1" cruise, carried out in spring 1991 in the eastern Alboran sea. Among the main results, the chlorophyll biomass was higher in the hydrological structures related to the frontal region (Atlantic jet and anticyclonic gyre) than in the surrounding Mediterranean oligotrophic waters (Claustre et al., 1994). The biomass of zooplankton was also the highest in the Atlantic water structures, as a consequence of the enhancement of its nutritional activity and metabolism (Thibault et al., 1994). The "Almofront 2" cruise, in December 1997-January 1998, was planned in order to test the results at another season, focusing on the influence of the internal hydrological structure and secondary circulation on biological production and on the export of matter in the Almeria-Oran frontal area. The results concerning the variations of biomass, abundance and composition of the mesozooplankton obtained during "Almofront II" are exposed in a previous paper (Youssara and Gaudy, 2001). The present work analyses the variations of the mesozooplankton physiological activities (respiration, excretion, feeding) in relation to the different hydrodynamic structures coexisting in the frontal region.

\section{Materials and methods}

\subsection{Study area, choice and characteristics of the sites}

The "Almofront 2" cruise was carried out in the eastern part of the Alboran sea, between $3-0^{\circ} \mathrm{W}$ and $36-35^{\circ} \mathrm{N}$ Fig. 1. The biological processes were studied from 24 December 1997 to 4 January 1998, at eight different sites Fig. 2 numbered according to their cruise chronology approach. They were chosen to represent the various zones of the frontal system, defined from the information obtained during the first part of the cruise, performed between the 13 and the 23 of December 1997 in the whole area. The location of each site followed the position of a buoy sustaining two sediment traps (100 and $300 \mathrm{~m}$ depth), drifting in the currents during two days. At each site, 10-12 CTD profiles were

ALMOFRONT 1997 - 1998 - LEG 2

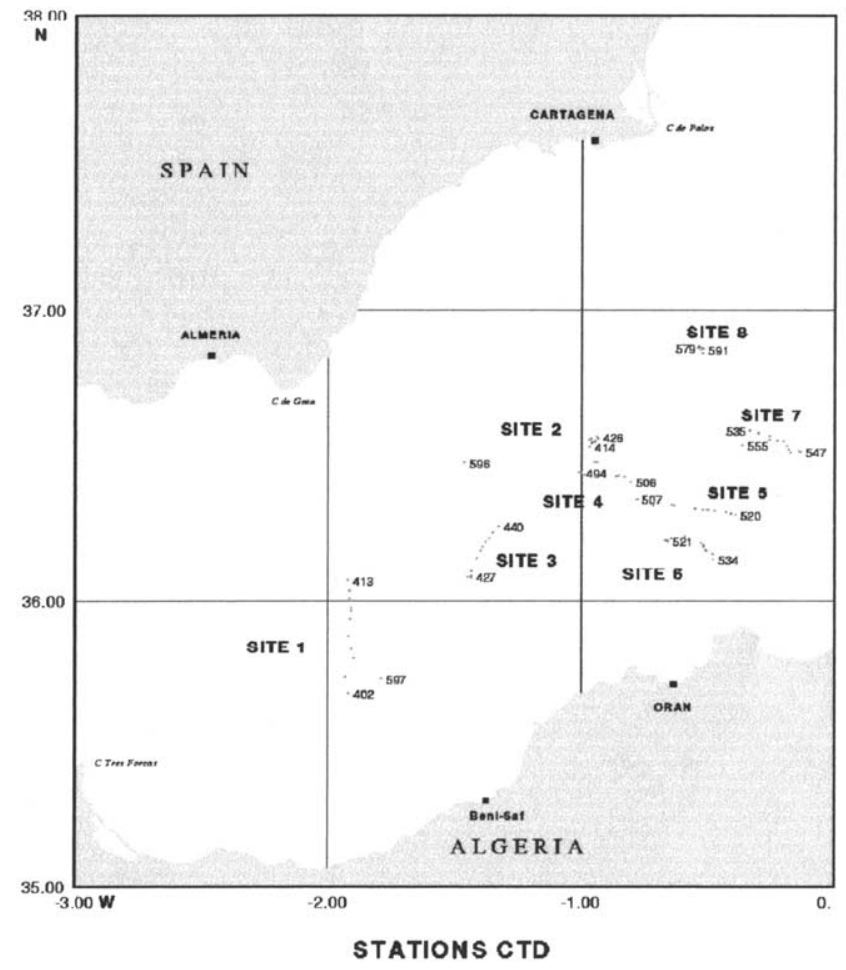

Fig. 1. Study area (east of the Alboran Sea). Location of the CTD stations performed during two successive days at each of the eight sites. 


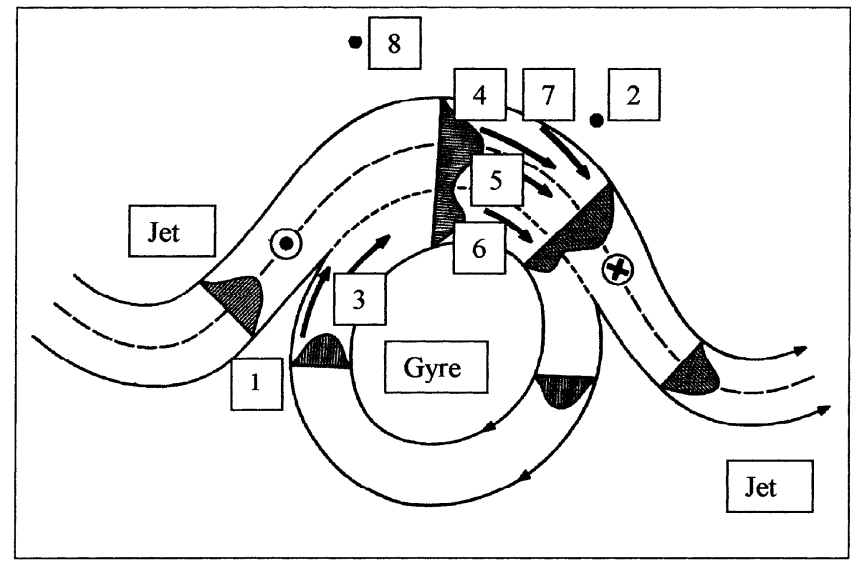

Fig. 2. Location of the sites with respect to the schematic horizontal structure of the Almeria-Oran front. Differences in the respective location of the sites as shown in Fig. 1 (geographical position) result from the displacement of the whole structure from west to east during the time of the cruise. Current's velocity is indicated by the shadow areas. The arrows represent the shift of the position of the sampling stations drifting in the current during the time of study of each site. Sites 8 and 2 are located in the Mediterranean water.

performed at regular intervals, in order to describe the hydrological features of the water column and to check the stability of the structure investigated. Site 1 was at the most western position, in the left part of the gyre, close to the right limit of the cyclonic meander of the Atlantic jet. Sites 3 and 6 were placed in the core of the gyre, upstream and downstream, respectively. Sites 4 and 5 , characterised by a relatively rapid current, were representative of the jet. Sites 8 and 2 were located in Mediterranean waters. The first was influenced by a secondary hydrodynamic structure characterised by a current flowing northward, contrary to Site 2 which was closer to the front. Site 7 was at the front limit, where the maximum horizontal density gradient was observed. At these different sites, the CTD 0-200 m profiles of temperature, salinity and fluorescence differed according to the degree of Mediterranean or Atlantic water influence. The intra-site variability (10-12 profiles) was largely lower than the inter-sites differences demonstrating the validity of the separation in different hydrological structures (Prieur, personal communication). Mediterranean sites displayed colder, saltier and poorer water than Atlantic sites. Specifically, the average water density Fig. 3) allows separating clearly the denser Mediterranean waters (Sites 8 and 2) from the lighter waters of the jet and gyre sites. At the frontal limit (Site 7) some differences appeared in surface water characteristics between the first day, when density values approached the Mediterranean ones, and the second day of investigation, with values closer to the jet water density. In this paper, the results obtained at the different sites are classified along a Mediterranean-Atlantic gradient, according to the density of surface water and the depth of the pycnocline (the deepest being observed in the gyre), in the following order: 8, 2 (Mediterranean water), 7a and $7 \mathrm{~b}$ (front limit; first and second day), 4, 5 (core of the jet) and 1, 6, 3 (anticyclonic gyre). Table 1 summarises the main

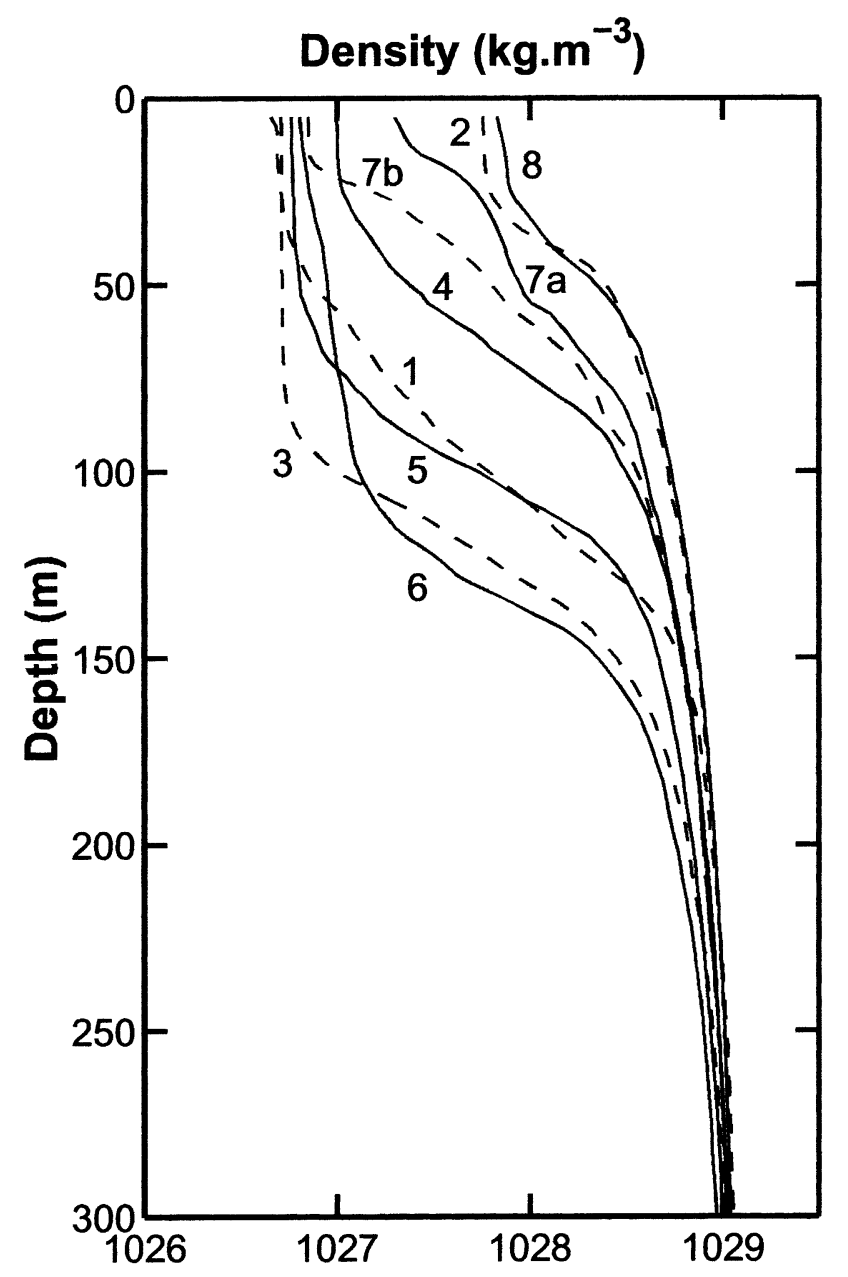

Fig. 3. Vertical profiles of the density of water at the eight sites. Site 7 is separated in two profiles ( $\mathrm{a}$ and $\mathrm{b}$ ) corresponding to day 1 and 2 .

features characterising the ecological conditions at the different sites.

\subsection{Sampling and treatment of biological material}

At each site, four plankton samples (corresponding to four different CTD stations) were taken, at night (04:00 hours) and during the day (11:00 hours), on two successive days. Zooplankton was sampled vertically between $200 \mathrm{~m}$ and the surface with a triple WP2 nets (UNESCO, 1968). One net, equipped with a $80 \mu \mathrm{m}$ mesh size silk, was used for copepod larval stage studies. The two others were equipped with a $200 \mu \mathrm{m}$ silk. One of the samples was used for biomass measurement and taxonomic analysis (Youssara and Gaudy, 2001) and the other, for shipboard experiments (twice per site). Generally, the first experiments started around 06:00 hours and the second, 6-7 $\mathrm{h}$ later.

Before the experiments, zooplankton was acclimated in surface sea water and in the dark during $2 \mathrm{~h}$. Zooplankton samples were cleared from big detritus or dead organisms and fractionated into ten parts. For incubation experiments, eight $300 \mathrm{ml}$ bottles were filled with sea water filtered on a $0.45 \mu \mathrm{m}$ membrane, called FW series hereafter and eight 
Table 1

Environmental characteristics of the sites investigated during Almofront II. Chlorophyll data (Claustre, Oubelkheir and Cuttelod, personal communication) were obtained from calibrated fluorescence measurements in the water column between 0 and $200 \mathrm{~m}$ (a) and from HPLC analysis of micro-, nano- and picoplankton taxinomical pigments (b)

\begin{tabular}{|c|c|c|c|c|c|c|c|c|c|}
\hline \multirow{2}{*}{$\begin{array}{l}\text { Hydrological } \\
\text { structure }\end{array}$} & \multirow[t]{2}{*}{ Site } & \multirow[t]{2}{*}{ Stations } & \multirow{2}{*}{$\begin{array}{l}\text { Pycnocline } \\
\text { (vertical extent) } \\
\text { (m) }\end{array}$} & \multirow{2}{*}{$\begin{array}{l}\text { Temperature } \\
\text { (surface) } \\
\left({ }^{\circ} \mathrm{C}\right)\end{array}$} & \multicolumn{2}{|l|}{ Salinity } & \multicolumn{3}{|c|}{$\mathrm{Chl} \mathrm{a}\left(\mathrm{mg} \mathrm{m}^{-2}\right)$} \\
\hline & & & & & (surface) $\left(\mathrm{g}^{-1}\right)$ & Total (a) & Micro (b) & Nano (b) & Pico (b) \\
\hline \multirow{2}{*}{$\begin{array}{l}\text { Mediterranean } \\
\text { water }\end{array}$} & 8 & $579,581,587,590$ & $25-50$ & 15.5 & 37 & 37 & 3 & 13 & 3.9 \\
\hline & 2 & $414,417,421,425$ & $25-50$ & 16 & 37.5 & 26 & 10 & 21 & 3.1 \\
\hline \multirow[t]{2}{*}{ Frontal limit } & $7 \mathrm{a}$ & 535,538 & $50-80$ & 15.9 & 37.1 & 70 & & & \\
\hline & $7 \mathrm{~b}$ & 543,545 & $15-100$ & 16.5 & 36.7 & 57 & 24 & 25 & 3.8 \\
\hline \multirow[t]{2}{*}{ Atlantic jet } & 4 & $494,497,501,505$ & $30-90$ & 16.3 & 37.5 & 59 & 21 & 21 & 2.1 \\
\hline & 5 & $507,510,514,518$ & $70-120$ & 17.1 & 36.7 & 60 & 22 & 31 & 1.6 \\
\hline \multirow{3}{*}{$\begin{array}{l}\text { Anticyclonic } \\
\text { gyre }\end{array}$} & 1 & $402,403,405$ & $40-150$ & 17.6 & 36.7 & 55 & 26 & 29 & 1.4 \\
\hline & 6 & $521,524,528,532$ & $120-170$ & 16.9 & 36.7 & 91 & 50 & 36 & 0.9 \\
\hline & 3 & $427,430,434,438$ & $90-170$ & 17.5 & 36.6 & 61 & 19 & 35 & 1.8 \\
\hline
\end{tabular}

other bottles, with unfiltered sea water coming from the surface ("UFW series"). For each series, zooplankton aliquots (similar number of about 100 individuals of $20 \mu \mathrm{g}$ as an average and specific composition: mainly copepods of C5 and C6 stages) were introduced in five of the bottles, while the three others, without zooplankton, served as controls. Incubation lasted for about $24 \mathrm{~h}$, at sea surface temperature and in the dark. Bottles of the UFW series were fixed on a vertically rotating wheel $(2 \mathrm{rpm})$ to avoid the sedimentation of particles. At the end of the incubation period, $30 \mathrm{ml}$ of water were withdrawn from each bottle and measured for oxygen concentration (YSI 53 oxymetre). In the FW series, two other $30 \mathrm{ml}$ volumes were taken for ammonium measurement, according to Koroleff (1969)'s method and for phosphate measurement (Strickland and Parsons, 1972). Finally, $100 \mathrm{ml}$ of water, taken from the bottles of the UFW series were used for the determination of particle concentration by a Coulter Counter model multisizer, equipped with a $70 \mu \mathrm{m}$ orifice tube allowing the counting of particles from 3 to $45 \mu \mathrm{m}$ equivalent spherical diameter (ESD). Zooplankton from the different experimental flasks was then checked for their physiological state (mortality rates less than 3-5\%), collected by sieving, dried in an oven then weighed later, at the land laboratory. Respiratory, excretory and ingestion specific rates were calculated from the difference of $\mathrm{O}_{2}, \mathrm{NH}_{4}$, $\mathrm{PO}_{4}$ and particle concentrations in the water of controls and tests bottles, taking into consideration the weight of incubated animals and the duration of the experiment. Food size selectivity was measured by comparing the particle distribution in control and test flasks, using the Paloheimo (1979)'s index $I_{i}=r_{i} / p_{i}$, where $r_{i}$ and $p_{i}$ are the proportion of prey in the control and test bottles, respectively, for a size class $i$. To utilise the same unity in the different analysis, $I_{i}$ was divided by $Z$, where $Z=\Sigma r_{i} / p_{i}$. Thus, for each class size $i$, the selectivity index was $I_{p}=I_{i} / Z$.

\subsection{Reproduction index and faecal pellets production}

The ratio of nauplii to adult copepods, the main component of the mesozooplankton community, was used as a crude index of their reproductive activity. These values were calculated from the average counts of the samples from the fine $(80 \mu \mathrm{m})$ net which collected more efficiently the nauplii and from the coarse $(200 \mu \mathrm{m})$ net, more adapted to the capture of the adults.

The production of faecal pellets was considered as an index of food activity (Mauchline, 1998). It was determined experimentally. Adult or C5 copepods (50 individuals, on an average) were placed in $50 \mathrm{ml}$ plastic tubes, closed by a silk of $200 \mu \mathrm{m}$ mesh size and immersed in $200 \mathrm{ml}$ finger bowls containing surface sea water. The faecal pellets produced passed through the mesh and settled at the bottom. At the end of the 6-9 h experiments, pellets and incubated animals were collected and preserved in sea water with 5\% formaldehyde until their counting, at the land laboratory. Three replicates were analysed per site. The faecal pellet production rates were calculated per individual and per hour.

\subsection{Environmental parameters and statistical treatment}

Temperature and salinity profiles were obtained from CTD records. Chlorophyll a concentration was measured in the sea water collected by a rosette at different vertical levels between the surface and $100 \mathrm{~m}$, using the fluorometric technique of Yentsch and Menzel (1963).

Anova was used for statistical comparisons when all data (80) were considered. For lower numbers of data, the non parametric Mann-Whitney test was preferred in order to avoid problems of non normality and inequality of variances.

\section{Results}

\subsection{General features of the zooplankton community}

Youssara and Gaudy (2001) gave detailed analysis of the mesozooplankton composition at the different sites. In the $200 \mu \mathrm{m}$ zooplankton samples, the bulk of the population is made of copepods (66-71\% of the total number). Their nauplii account for $1-7 \%$, the rest of holoplankton, for $25-27 \%$ and meroplankton, only for $1-3.5 \%$. In the samples collected by the fine net ( $80-\mu \mathrm{m}$ size mesh), the proportions 

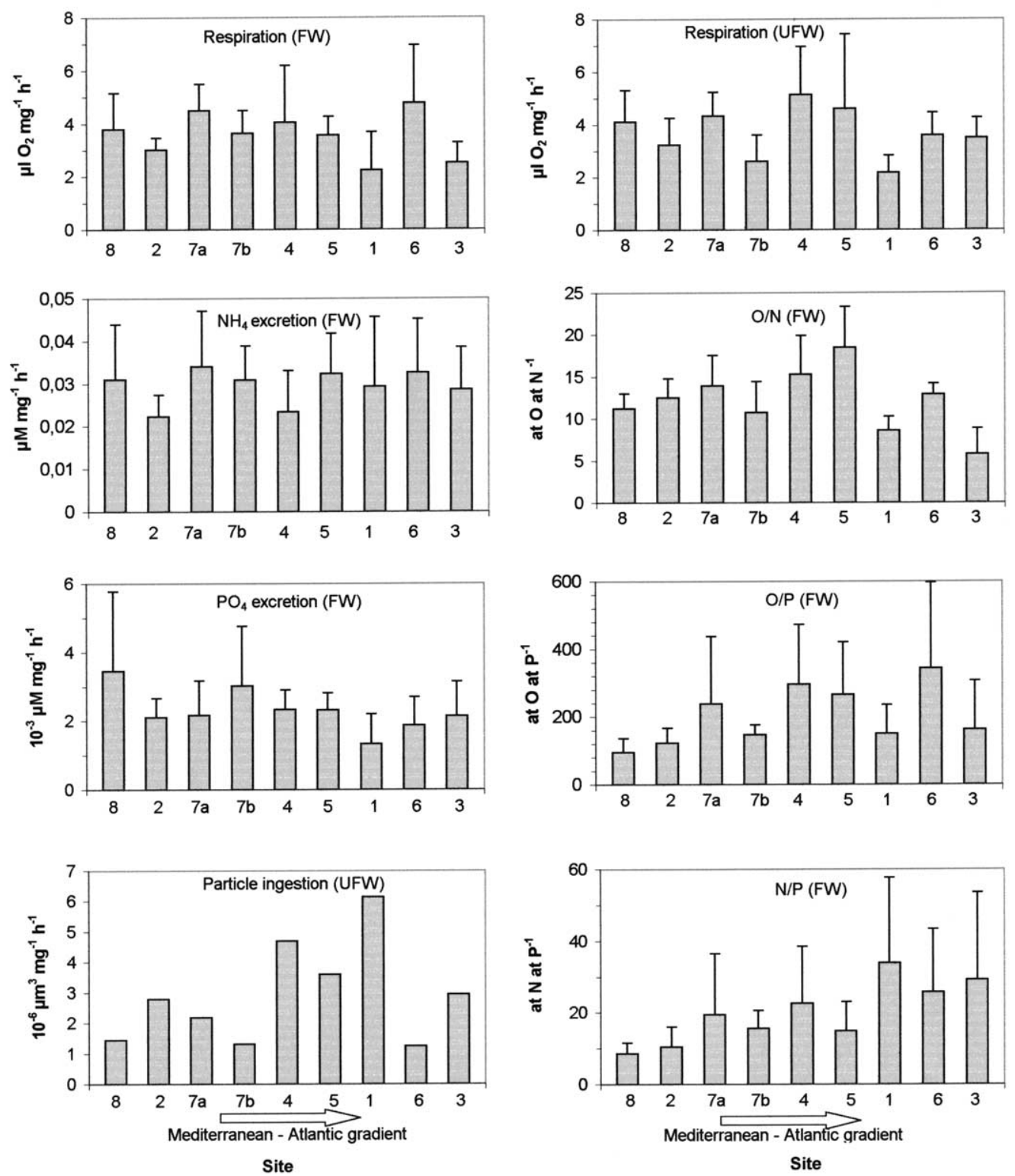

Fig. 4. Variation of respiration, ammonium and phosphate excretion rates, $\mathrm{O} / \mathrm{N}, \mathrm{O} / \mathrm{P}$ and $\mathrm{N} / \mathrm{P}$ atomic ratios and particle grazing rates (mean $\pm \mathrm{S} . \mathrm{D}$.). (FW), filtered sea water; (UFW), unfiltered sea water.

are different, the nauplii making $30-39 \%$ of the total number. The relative abundance of the main groups remains relatively constant at the different sites, except for meroplankton which displays significant differences with a minimum percentage at site 8 and higher values at the Atlantic water-influenced sites. A total of 55 copepod species were identified. In the overall studied area, $72 \%$ of the individuals belong to four genera only. Clausocalanus predominates (43\%). It is followed by Oithona (10.5\%) and by Pleuromamma (9.3\%). The fourth genus, Oncaea, accounts for $9 \%$ of the individuals. Despite the different hydrodynamic conditions, there was little difference between the overall mesozooplankton composition at the different sites.

\subsection{Physiological rates}

As the average results of the two or three successive experiments performed in each site were not significantly different (Anova; $F=1.4 ;$ n.s.), a mean value was calculated per site on the basis of 15 (only site 6) or 10 (other sites) replicates (Fig. 4 ).

In the FW series, significantly higher respiration values were recorded at the stations located at the front (site 7), compared to the lower rates found in the Mediterranean sites (sites 8,2) (Mann-Whitney test: $U=38<m_{0.01}=42$ ) but no significant difference appeared between the front value (site 7) and the rates found in water from Atlantic origin (sites 4, 5, 
1, 6, 3). Inside the gyre, the high value occurring at site 6 contrasted with the low rates found at sites 1 and 3 (Mann-Whitney, $U=21<m_{0.01}=42$ ).

In the UFW series, the respiration rates observed at each site did not differ significantly from the values obtained at the corresponding sites of the FW series (Anova; $n=14 ; F=$ 1.23 ; n.s.).

Considering all the stations, ammonium excretion rates were not significantly different (Anova; $F=1.85 ;$ n.s.). Nevertheless, the value found at the front (site 7) exceeded the values found at the adjacent sites (Mann-Whitney; $U=24<$ $m_{0.01}=29$ for the comparison with site 2 and $U=35<m_{0.01}$ $=39$, comparing with site 4$). \mathrm{PO}_{4}$ excretion varied significantly according to the different sites $(F=2.89 ; P<$ $0.01)$.The values recorded at the gyre sites were significantly lower than those at the other stations (Mann-Whitney; $U$-test; $P<0.2) . \mathrm{O} / \mathrm{N}, \mathrm{O} / \mathrm{P}$ and $\mathrm{N} / \mathrm{P}$ atomic ratios differed significantly according to the different structures $(F=11.82$, 2.6 and 2.78, respectively). Lowest $\mathrm{O} / \mathrm{N}$ and highest $\mathrm{N} / \mathrm{P}$ values were found in the gyre $(F=26.99 ; P<0.000$ and $F=$ $10.37 ; P<0.002$, respectively). $\mathrm{O} / \mathrm{P}$ values were significantly lower in Mediterranean water than in other structures $(F=$ 9.52; $P<0.003)$.

Significantly higher particle ingestion was found in the Atlantic jet and also at site 1 compared to other stations (Mann-Whitney; $U=0$ ). Some particle spectra characterising the different sites are presented on Fig. 5. In the Mediterranean water, small and medium-size particles $(8-20 \mu \mathrm{m})$ were the most numerous and few large particles (over $30 \mu \mathrm{m}$ ) were observed. On the contrary, at the front, on the first day (7a) large particles were more abundant, while, on the second day, this tendency was very dampened, confirming the drift of the station toward jet water demonstrated by the hydrological study. In the Atlantic jet (sites 4 and 5) two peaks of particle frequency appeared, at sizes around $10 \mu \mathrm{m}$, and between 30 and $40 \mu \mathrm{m}$. At the gyre sites, the spectra displayed a maximum of frequency around $10-18 \mu \mathrm{m}$, but big particles were scarce, except at site 6 where a small peak around $35 \mu \mathrm{m}$ appeared. The ingestion varied differently according to particle size. The selectivity index of Paloheimo (1979) was used to illustrate the different patterns observed. In most cases food selectivity appeared for a given part of the size spectrum. To simplify the presentation of the results, average values of the index were calculated for different particle size ranges $(3-5,5-10,10-20,20-30,30-40$ and $40-45 \mu \mathrm{m}$ ). Fig. 6 shows that the selection pattern varied according to sites. In Mediterranean waters, small and medium sized particles were selected rather than large particles. This contrasted with the pattern observed at the front where selectivity increased with particle size (7a) or was maximum at 20-30 $\mu \mathrm{m}$. In the Atlantic jet, the same pattern was observed: maximum selectivity between 10 and $40 \mu \mathrm{m}$ particles while the small cells were neglected or poorly chosen. In the gyre water, maximum selectivity was observed for mediumsized particles but small particles $(<5 \mu \mathrm{m})$ were also selected at sites 6 and 3 .
The "reproduction index" displayed its maximum values at site 6, in the gyre structure (Mann-Whitney; $U=0$ ), and was minimum at the Mediterranean sites 8 and 2 (Fig. 7 ).

The production of faecal pellet was enhanced at site 6 Fig. 8) but increased also at the two Mediterranean sites 8 and 2. The Anova showed that the production of faecal pellets was significantly higher at site 6 than at the other sites $(F=$ 5.16; $P<0.027)$.

\section{Discussion and conclusion}

\subsection{Physiological activity and hydrological structure}

In the investigated area, zooplankton abundance and biomass were positively correlated to chlorophyll concentration (Youssara and Gaudy, 2001). Low chlorophyll concentrations found at the Mediterranean sites 2 and 8 (26 and $37 \mathrm{mg} \mathrm{m}^{-2}$, respectively), contrasted with the values measured at the sites influenced by Atlantic water, where they reached $91 \mathrm{mg} \mathrm{m}^{-2}$ Table 1. Maximum zooplankton biomass and abundance values were observed at Site 6 where highest chlorophyll and microphytoplankton concentrations were recorded Table 1. As already demonstrated in May (Thibault et al., 1994), the increase of zooplankton biomass in the frontal system of the eastern Alboran sea is not due to an accumulation process by horizontal transport but seems rather the consequence of a local enhancement of the secondary production. Several clues support this hypothesis. They are relevant to feeding activity and to population age structure.

Metabolism variations with respect to sites cannot be attributed to significant changes in zooplankton assemblage and/or differences in temperature conditions. More likely, they correspond to different levels of physiological expenses, likely related to feeding activity. As a matter of fact, increase of feeding results in a respiration enhancement, due to the higher energy expenditure of feeding animals (specific dynamic action, SDA), because of the cost of various processes (food collection, digestion, etc.), among which biosynthesis of organic compounds may be dominant (Kiørboe et al., 1985). High zooplankton respiration rates found at the front and jet stations contrasted with the lower values recorded at Mediterranean and gyre sites (except for site 6). The same result was obtained in May, during the "Almofront 1" cruise (Thibault et al., 1994). Respiration increase in Atlantic jet water reflects the cost of the enhancement of feeding activity, as indicated by the increase of particle ingestion in the jet. Discrepancies appear at the frontal limit and at site 6 where high respiration corresponded to low particle ingestion. This could be related to the presence of food particles at these stations, which are richer in chlorophyll content that could allow the zooplankton to complete more easily its energy needs without increasing its filtering activity. As a matter of fact, sites 7 and 6 were more favourable for feeding upon plant material than the others. Site 6 was the place where highest chlorophyll concentration and microphytoplankton 

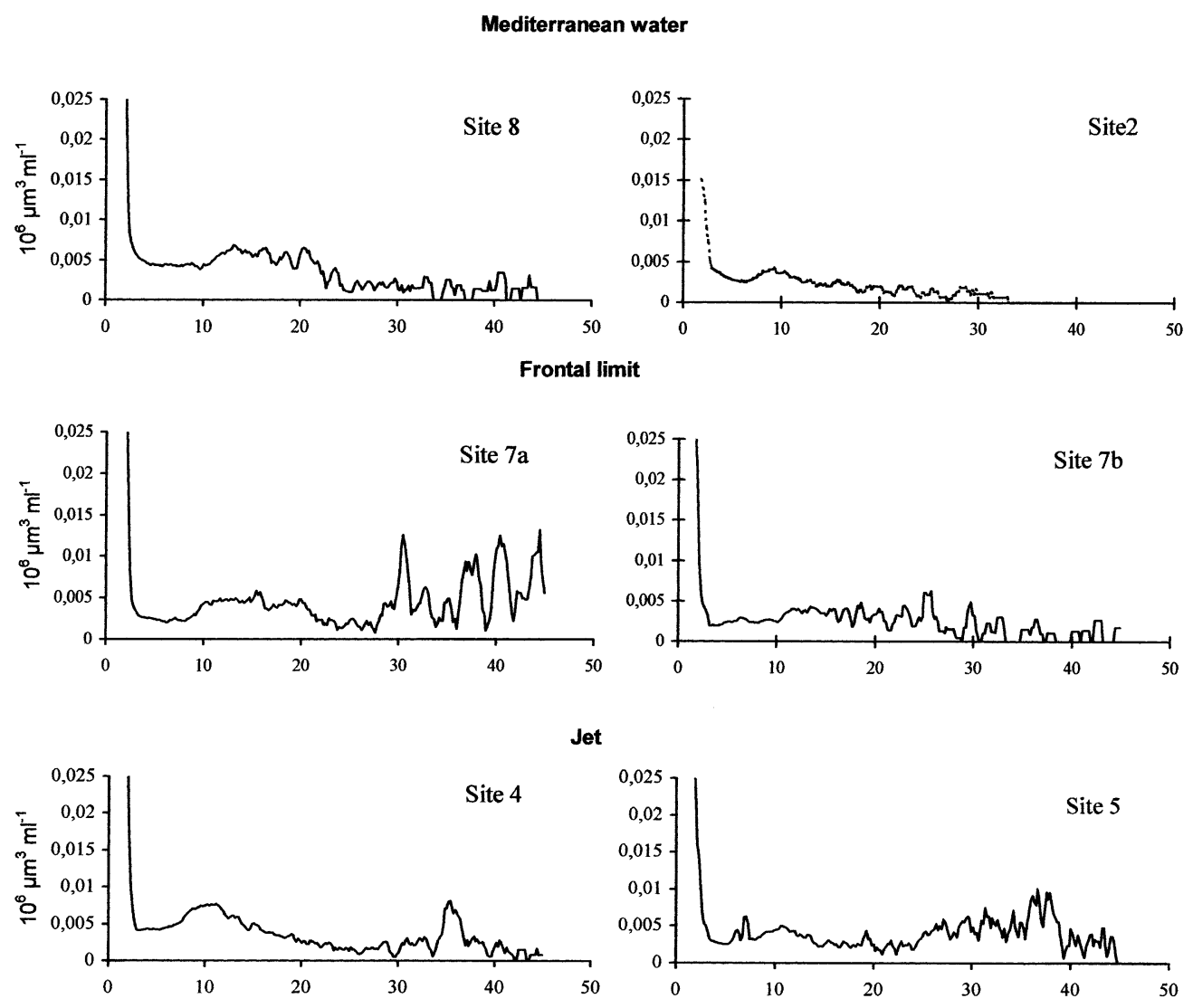

Gyre
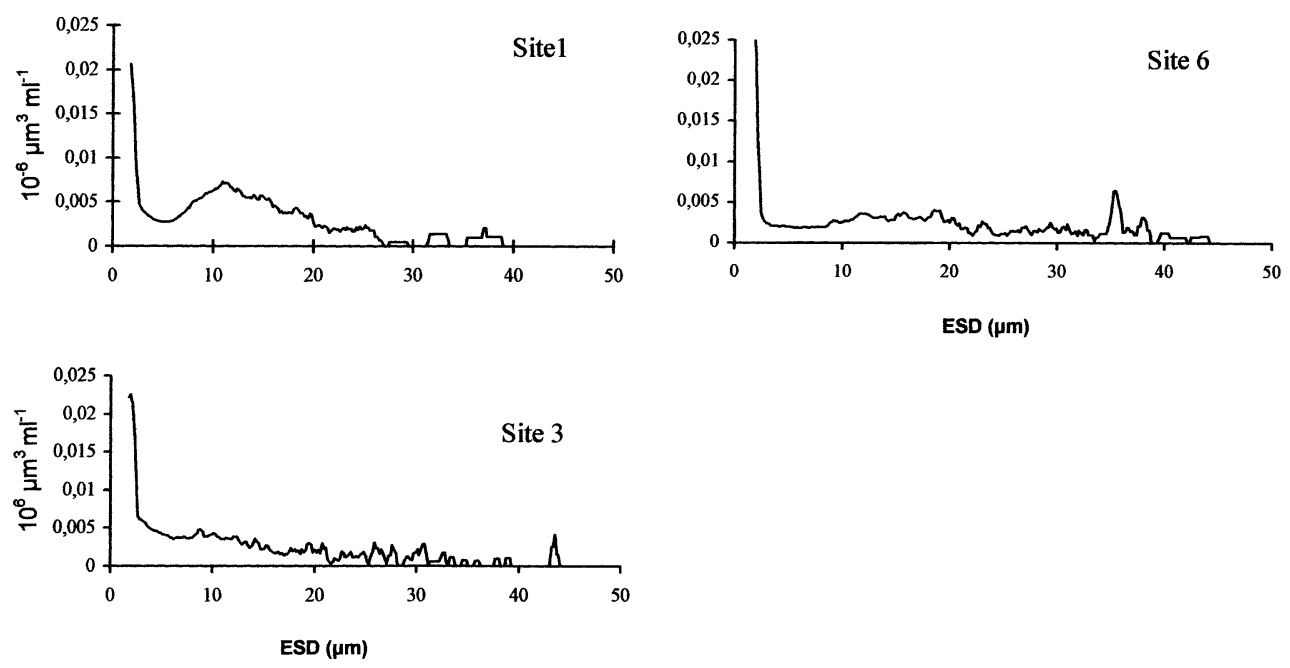

Fig. 5. Particle spectra at the different sites investigated (average values of successive experiments per site). ESD is the equivalent spherical diameter.

abundance occurred (Claustre et al., unpublished results). At the frontal limit (Site 7), maximum zooplankton grazing activity was inferred from the examination of the organic material collected by the sediment traps: the highest proportion of phytol, a selective index of phytoplankton degradation, was found at this site (Striby and Goutx, unpublished results).
Ammonium excretion increased at the front as also found at the Balearic front by Alcaraz et al. (1994), suggesting a special enhancement of feeding activity at this site. Increase of food catabolism in Atlantic sites was also indicated by the increase of phosphate excretion. Atomic ratios $\mathrm{O} / \mathrm{N}, \mathrm{O} / \mathrm{P}$ and $\mathrm{N} / \mathrm{P}$ can be used as a clue to the nature of substrata (carbohydrates or lipids vs. proteins) being oxidised through respira- 
Selectivity index

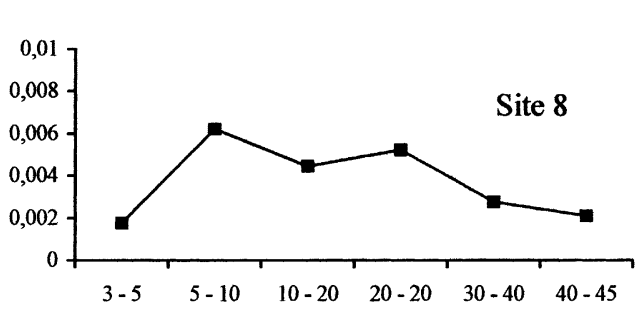

\section{Mediterranean water}

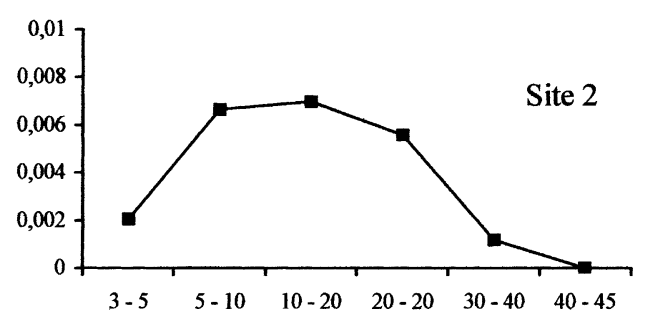

Frontal limit

Selectivity index

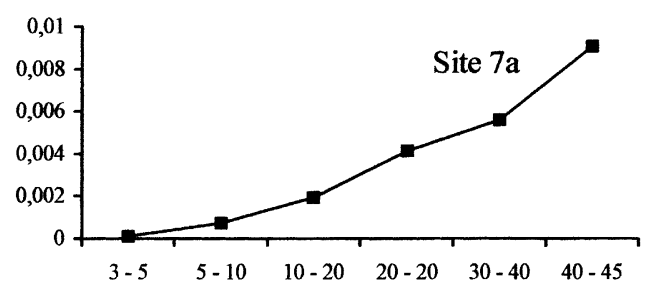

Selectivity index

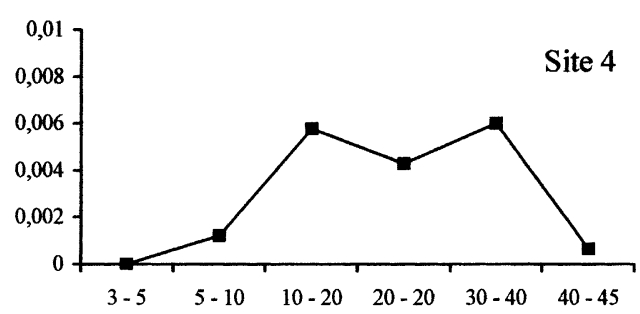

Selectivity index

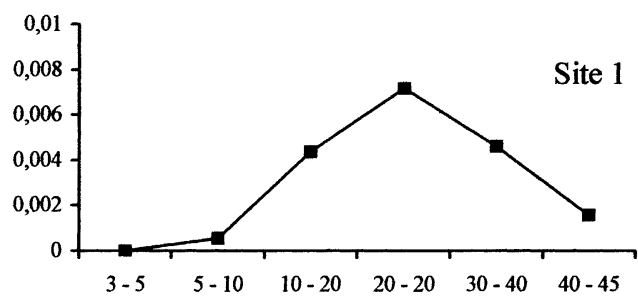

Selectivity index

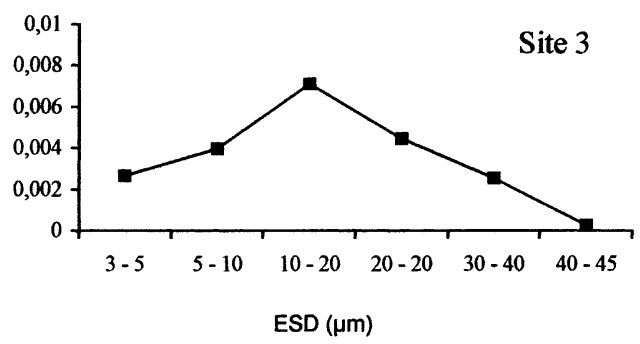

Atlantic jet

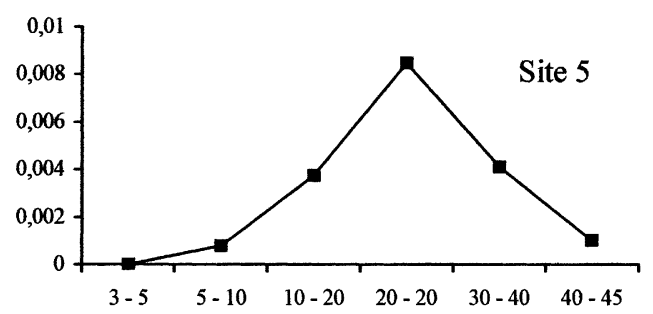

Gyre

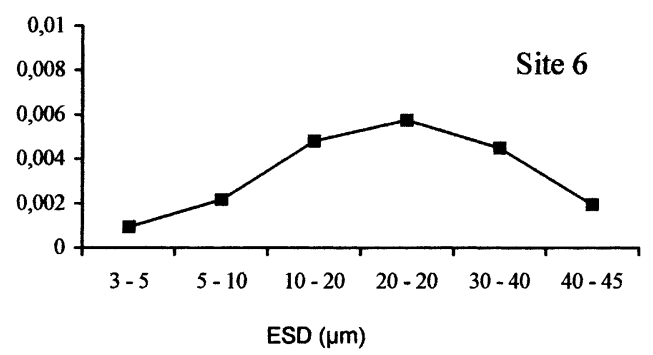

Fig. 6. Values of the Paloheimo selectivity index for grazing with in different particle size ranges. 


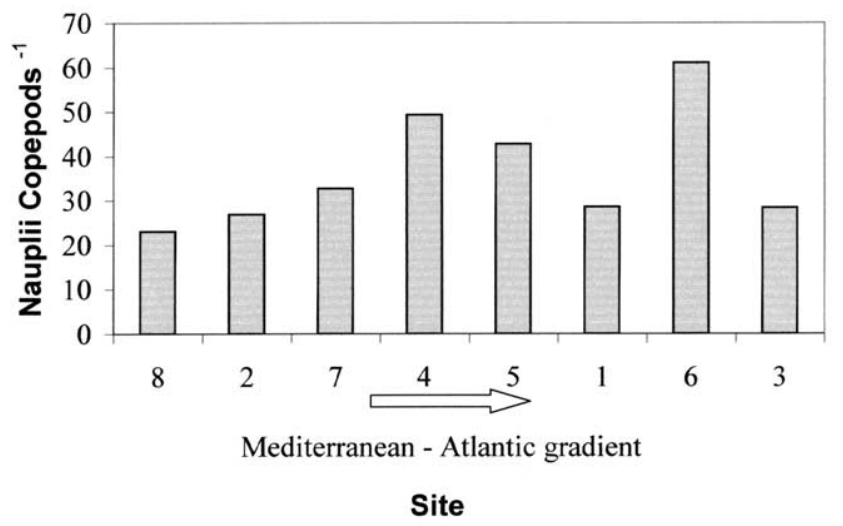

Fig. 7. Reproduction index (number of nauplii per adult copepods) in zooplankton: average values of 200 and $80 \mu \mathrm{m}$ mesh-size plankton nets data (mean of two stations per site).

tion (Gaudy and Boucher, 1982; Le Borgne, 1986). Values close to 17 for $\mathrm{O} / \mathrm{N}, 276$ for $\mathrm{O} / \mathrm{P}$ and 16 for N/P are generally considered as indicating the use of a food corresponding to the average chemical constitution of particles present in sea water (Omori and Ikeda, 1984). The theoretical minimum of $\mathrm{O} / \mathrm{N}$ ratio (exclusive use of proteins) is evaluated between 7 and 9 according to various authors (Conover and Corner, 1968; Ikeda 1974). Thus high $\mathrm{O} / \mathrm{N}$ and $\mathrm{O} / \mathrm{P}$ values indicate a feeding upon carbohydrate dominated material (plant food) while low values show the use of protein and lipid-dominated metabolisms, respectively (Omori and Ikeda, 1984).

During Almofront cruise, highest $\mathrm{O} / \mathrm{N}$ and $\mathrm{O} / \mathrm{P}$ values were found in the jet, and also at site 6 , in the gyre, suggesting that feeding was mainly oriented towards plant utilisation at these stations that were characterised by their chlorophyll richness (Claustre et al., unpublished results). This agree well with the respiration enhancement observed at the jet and at site 6 . On the contrary, maximum N/P and minimum $\mathrm{O} / \mathrm{N}$ ratios observed at the two other sites of the gyre suggest an orientation of the feeding behaviour toward more utilisation of animal prey such as microzooplankton or detritus, possibly harbouring attached bacteria and their protozoan predators. The general pattern of $\mathrm{O} / \mathrm{N}$ variations according to the more or less oligotrophic character of the different structures is in accordance with previous observations made during

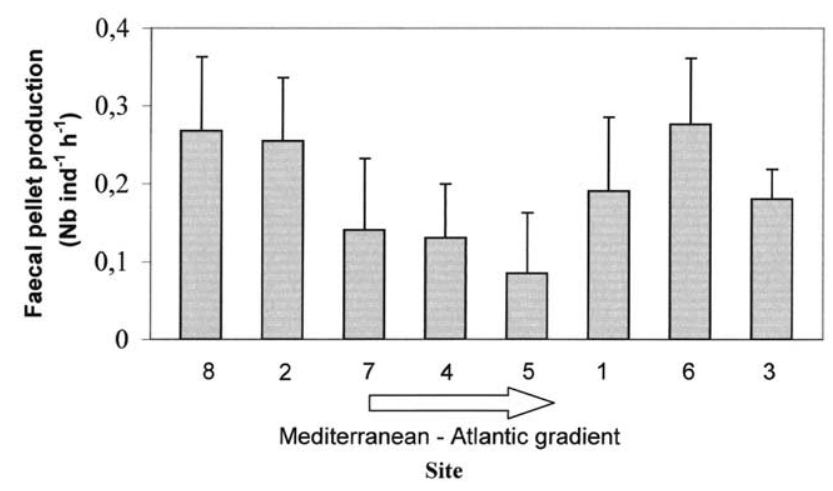

Fig. 8. Production of faecal pellets by copepods at the different sites investigated (mean \pm S.D.).
Almofront 1 cruise, in May (Thibault et al., 1994). Similar variations of $\mathrm{O} / \mathrm{N}$ ratios according to the degree of food richness were also found at a fixed station off Marseille, alternatively influenced by rich coastal water or by the oligotrophic North-Mediterranean Current (Christaki et al., 1996).

\subsection{Effect of particle size upon feeding}

The size of dominant phytoplankton seems also to play an important role on feeding activity. Microphytoplankton was two- to four-times more abundant at Atlantic sites than at Mediterranean ones Table 1). The particle spectra showed the presence of cells $>30 \mu \mathrm{m}$, corresponding to the size of most microplanktonic diatoms, at the front and jet sites, and also at site 6 . This contrasts with their absence or scarcity in Mediterranean and gyre sites 1 and 3. In our feeding experiments, selectivity was generally maximum for large particles, but smaller ones (3-5 and 5-10 $\mu \mathrm{m})$ were also selected in Mediterranean and gyre sites. Picoplankton was abundant in the Mediterranean sites, while, in the gyre, sites 3 and 1 contained relatively more picoplankton than site 6 where microplankton was dominant Table 1. Picoplankton would constitute a part of an enhanced bacterial food chain sheltering an increased microzooplankton community (Nielsen and Richardson, 1989). Large flagellates or ciliates associated to this chain could be used for food by mesozooplankton (Sherr et al., 1986; Stoecker and Capuzzo, 1990). As more nitrogen is excreted by copepods when protists are used as prey (Anderson, 1992), this would explain the low $\mathrm{O} / \mathrm{N}$ values found at Mediterranean sites and in the gyre, at sites 3 and 1. The same observation was made previously in the gyre structure explored during "Almofront 1", in spring (Thibault et al., 1994).

\subsection{Space variations of reproduction activity}

In the Almeria-Oran front area, highest proportions of nauplii were found in the jet and in the gyre, at site 6 , similarly to previous observations made in May, during Almofront I (Thibault, unpublished results). As seen before, these sites were the most favourable to chlorophyll biomass and microphytoplankton abundance. The quality of phytoplankton probably also plays an important role in zooplankton reproduction success. According to Kiørboe and Nielsen (1994), highest egg production rates are often related to the dominance of diatoms in microphytoplankton. These algae were abundant in the frontal structures of the area investigated (Vescovali et al., unpublished results; Claustre et al., 2000). A similar observation was also made during "Almofront I". The abundance of diatoms at the front was the result of an active new production fuelled by the advection of nutrients into the euphotic zone by the secondary circulation (Prieur et al., 1993; Fiala et al., 1994; L'Helguen et al., 2002). At the frontal limit, the $\mathrm{C} / \mathrm{Chl}$ a ratio of particles was close to 50 (Claustre and Oubelkheir, unpublished results), indicating a material mainly composed of freshly produced phyto- 
plankton. These favourable conditions would lead to maximum copepod egg production near the front boundary. As an isopycnal downwelling transfer of primary and secondary production occurs from the left to the right side of the jet (Prieur et al., 1993; Seguin et al., 1994; Pedrotti and Fenaux, 1996), the eggs produced at the left side of the jet (site 7) would develop during their transportation towards site 6 where maximum proportion of nauplii was found. Nevertheless, a local enhancement of the egg production at site 6 was also probable, taking into account the qualitatively (high proportion of diatoms) and quantitatively (chlorophyll and microphytoplankton abundances) favourable food conditions, compared to adjacent sites. The supplementary energy needed for reproduction is then provided by the increase of feeding activity, as attested by the enhancement of faecal pellets production at this site.

\section{Conclusion}

In the Almeria-Oran front area, significant variations appear in zooplankton biomass and physiological rates within a limited scale of space as already demonstrated at places where hydrodynamical singularities such as fronts, eddies or upwellings occur (Legendre and Le Fèvre, 1989). Vertical advections transporting the enriched water into the euphotic zone induce the enhancement of the new production at the frontal structure while regenerated production is pre-eminent at more stable water bodies such as oligotrophic Mediterranean water or Atlantic gyre. As the geostrophic front works as a quasi permanent structure, zooplankton can take benefit of the favourable food conditions by increasing its reproductive and growth rates, which results in an enhancement of the mesozooplankton biomass in the whole frontal area. This increase in secondary production process is attested by the activation of respiration and excretion in relation with food abundance and quality, and by the higher proportion of young developmental stages.

\section{Acknowledgements}

We would like to thank L. Prieur for his constructive advice on the interpretation of the hydrodynamic structures and the crew of R/V L'Atalante for their material help during the cruise. This work was supported by CNRS and Frontal (JGOFS-France) programme. Unpublished results cited in the text were presented at several meetings dealing with Almofront 1 and Almofront 2 cruises in the frame of JGOFS/France, in 1992 (Brest) and 1999 (Marseille).

\section{References}

Alcaraz, M., Saiz, E., Estrada, M., 1994. Excretion of ammonia by zooplankton and its potential contribution to nitrogen requirements for primary production in the Catalan sea (NW Mediterranean). Mar. Biol. 119, 69-76.

Anderson, T.B., 1992. Modelling the influence of food C:N ratio, and respiration on growth and nitrogen excretion in marine zooplankton and bacteria. J. Plankt. Res. 14, 1645-1671.

Arnone, R.A., Wiesenburg, D.A., Saunders, K.D., 1990. The origin and characteristics of the Algeria Current. J. Geophys. Res. 95, 1587-1598.

Christaki, U., Van Vambeke, F., Christou, E., Conan, P., Gaudy, R., 1996. Food web structure variability in the surface layer at a fixed station influenced by the North Western Mediterranean Current. Hydrobiologia 321, 145-153.

Claustre, H., Kerhervé, P., Marty, J.C., Prieur, L., Videau, C., Heck, J.H., 1994. Phytoplankton dynamics associated with a geostrophic front: ecological and biochemical implications. J. Mar. Syst. 5, 711-742.

Claustre, H., Fell, F., Oubelkheir, K., Prieur, L., 2000. Continuous monitoring of surface optical properties across a geostrophic front: biogeochemical inferences. Limnol. Oceanogr. 45, 309-321.

Conover, R.J., Corne, E.D.S., 1968. Respiration and nitrogen excretion by some marine zooplankton in relation to their life cycle. J. mar. biol. Ass. U.K. 48, 49-75.

Fiala, M., Sournia, A., Claustre, H., Marty, J.C., Prieur, L., Vétion, G., 1994. Gradients of phytoplankton abundance, composition and photosynthesis pigments across the Almeria-Oran front (SW Mediterranean sea). J. Mar. Syst. 5, 223-233.

Folkard, A.M., Davies, P.A., Prieur, L., 1994. The surface temperature fields and dynamical structure of the Almeria-Oran front from simultaneous shipboard and satellite data. J. Mar. Syst. 5, 205-222.

Gaudy, R., Boucher, J., 1982. Relation between respiration, excretion (ammonia and inorganic phosphorus) and activity of amylase and trypsin in different species of pelagic copepods from an Indian Ocean equatorial area. Mar. Biol. 75, 37-45.

Ikeda, T., 1974. Nutritional ecology of marine zooplankton. Mem. Fac. Fish., Hokkaido Univ. 22, 1-97.

Kiørboe, T., Nielsen, T.G., 1994. Regulation of zooplankton biomass and production in a temperate coastal ecosystem. I. Copepods. Limnol. Oceanogr. 39, 493-507.

Kiørboe, T., Møhlenberg, F., Hamburger, K., 1985. Bioenergetics of the planktonic copepod Acartia tonsa: relation between feeding, egg production and respiration, and composition of specific dynamic action. Mar. Ecol. Prog. Ser. 26, 85-97.

Koroleff, F., 1969. Direct determination of ammonia in natural water as Indophenol blue. ICES. CM/C 9 pp.

Le Borgne, R., 1986. The release of soluble end products of metabolism. In: Corner, E.D.S., O'Hara, S.C.M. (Eds.), The Biological Chemistry of Marine Copepods. Oxford University Press, Oxford, pp. 109-164.

Le Fèvre, J., 1986. Aspects of the biology of frontal of systems. Adv. Mar. Biol. 23, 169-199.

Legendre, L., Le Fèvre, J., 1989. Hydrodynamic singularities as controls of recycled versus exportation production in oceans. In: Berger, W.E.V., Smetacek, Wefer, S.G. (Eds.), Productivity of the ocean: Present and Past. Wiley, Chichester, pp. 49-63.

L'Helguen, S., Le Corre, P., Madec, C., Morin, P., 2002. New and regenerated production in the Almeria-Oran front area, eastern Alboran sea. Deep-Sea Res. I 49, 83-99.

Mauchline, J., 1998. The biology of calanoid copepods. Adv. Mar. Biol. 33, $1-710$.

Nielsen, T.G., Richardson, K., 1989. Food chain structure of the North sea plankton communities: seasonal variations of the role of the microbial loop. Mar. Ecol. Prog. Ser. 56, 75-87.

Omori, M., Ikeda, T., 1984. Methods in Marine Zooplankton Ecology. Wiley, New York p. 332.

Paloheimo, J.E., 1979. Indices of food type preference by a predator. J. Fish Res. Bd. Can. 36, 470-473. 
Pedrotti, M.L., Fenaux, L., 1996. Distribution of echinoderm larval populations in the geostrophic frontal jet of the eastern Alboran sea. Oceanol. Acta 19, 385-395.

Prieur, L., Copin-Montaigut, C., Claustre, H., 1993. Biophysical aspects of "Almofront 1", an intensive study of a geostrophic frontal jet. Ann. Inst. Oceanogr. Paris 69, 71-86.

Prieur, L., Sournia, A., 1994. "Almofront-1" (April-May 1991): an interdisciplinary study of the Almeria-Oran geostrophic front. SW Mediterranean sea. J. Mar. Syst. 5, 187-203.

Seguin, G., Ehrif, A., Dallot, S., 1994. Diversity and structure of pelagic copepod populations in the frontal zone of the eastern Alboran sea. Hydrobiologia 292/293, 369-377.

Sherr, E.B., Sherr, B.F., Paffenhöfer, G.A., 1986. Phagotrophic protozoa as food for metazoans: a "missing" link in pelagic food webs? Mar. Microb. Food Webs 1, 610-680.

Stoecker, D.K., Capuzzo, J.M., 1990. Predation on protozoa; its importance to zooplankton. J. Plankt. Res. 12, 891-908.
Strickland, J.D.H., Parsons, T.R., 1972. A practival hand book of seawater analysis. $2^{\text {nd }}$ ed. Bull. Fish. Res. Bd. Can. 137, 1-311.

Thibault, D., Gaudy, R., Le Fèvre, J., 1994. Zooplankton biomass, feeding and metabolism in a geostrophic frontal area (Almeria-Oran Front, western Mediterranean). J. Mar. Syst. 5, 297-311.

Tintore, J., La Violette, P.E., Blade, I., Cruzado, A., 1988. A study of an intense density front in the eastern Alboran sea: the Almeria-Oran front. J. Phys. Oceanogr. 18 (10), 1384-1397.

UNESCO, 1968. Zooplankton sampling. UNESCO Monogr. Oceanogr. Methodol., 2. UNESCO press, Paris p. 174.

Yentsch, C.S., Menzel, D.W., 1963. A method for the determination of phytoplankton chlorophyll and phaeophytin by fluorescence. Deep-Sea Res. 10, 211-231.

Youssara, F., Gaudy, R., 2001. Variations of zooplankton in the frontal area of the Alboran sea (Mediterranean sea) in winter 1997. Oceanol. Acta 24, 361-376. 